\title{
Assistance of the Arbëresh Personalities for the Preservation and Development of the Albanian Language
}

\author{
Monica Hasan (Hoshafi)
}

Ministry of Education Sports

Email:mhasani@yahoo.com

\section{Doi:10.5901/jesr.2015.v5n1p79}

\begin{abstract}
Although Arbèresh community removed to Italy since nearly five centuries ago, they continued to jealously guard their traditions and ancient rites, aiming to keep alive proudly their fore-fathers world. During their hard work how to protect and highlight the " Arbëresh world ", they had to overcome numerous difficulties of linguistic and literary character in their native language writing. The Arbèresh community of Italy wrote in the native language and the first known writer until today among them was Lek Matrënga with his masterpiece "E mbsuame e krishterë" (1592). Under the influence of Italian Language, as well as under the influence of the Roman Catholic culture, the arbëresh writers have used mainly Latin alphabet. In 1836 De Rada for the first time published in Napoli "Songs of Milosaos". In the foreword of this wonderful lyric poem, the powerful researcher expressed deep concern for the preservation of the Albanian identity and arberesh folk songs. Even today his creative work is an inspiration source and a subject of study for a considerable number of albanologists, linguists and teachers of the Albanian language.
\end{abstract}

Keywords: De Rada, Arbereshe, Albanian language,

\section{Introduction}

Although Arbèresh community removed to Italy since nearly five centuries ago, they continued to jealously guard their traditions and ancient rites, aiming to keep alive proudly their fore-fathers world. In hard conditions they have reproduced and preserved among them the identity, ethnic consciousness, language, culture, religion and the strong spirit of solidarity. Remembrance and heroism of George Kastrioti Skanderbeg represents "the myth of origin" for Arbëresh, thus creating the identity of being arbëresh, who said in names, toponimy (rhapsody) of folklore. Legendary era of Skanderbeg found its place among Arbëresh community, it became part of their cultural tradition.

Permanent members of efforts who tried to preserve national identity have been and continued to be the arbëresh writers, poets and arberesh scholars. Many of them are such legendary figures to be highly respected as: Francesco Solana, Zef Skiroi, Gabriele Dara, Demetrius Mara, Michele Markianoi, Francesco Altimari etc.

During their hard work how to protect and highlight the "Arbëresh world", they had to overcome numerous difficulties of linguistic and literary character in their native language writing. The Arbèresh community of Italy wrote in the native language and the first known writer until today among them was Lek Matrënga with his masterpiece "E mbsuame e krishterë" (1592). Arbëresh Culture assumed full development during the 18th century, at a time when a number of prominent Arberesh emerged, as: Julius Varibova, Nikole Filia, Nikole Frankati, Nikole These, Father George Guceta, Zef Barca Francesca Avati, etc.

At the very beginning of its developments, Arberesh scholarly writings were mainly of religious nature. While the 19th century could be a period of prosperity for the literature its irreligious (laic) and patriotic character could be noticeable by the Arbëresh view. The folklore Summary of De Rada "Rhapsodist of an Albanian poem" (1886), was one of the most important among the first editions of this period; after this edition there were published various folklore summaries by other researchers as: Zef Skiroi, Mikel Markianoi Antonio Skura etc.

The character of Jeronim de Rada would consistently be the most famous and distinguished among arberesh scholars during this period. It could be an Albanian great patriot who fought strongly for the development of education and culture. The Albanian lyrical poet was undoubtfully influenced by patriotic feelings. With the features of spiritual and artistic inspiration in the Arbëresh culture, De Rada remained a further brilliant and fore-father's world model, number two after Skanderbeg's hero. The work of De Rada had a very strong impact on young literary world politicians of that time and on activists of the national renaissance. College of "Saint Adrian" directed by him was turned into a source where 
Albania prepared independent teachers and to those who built the new Albanian state. Established in 1732 College St. Uterus arbëresh krone gave the most valuable contribution to the school regarding Albanian pedagogical language opinion. In this college great patriots worked like: Zef Serembe, George Guxeta, angel Mash. Dora d'Istria would express the opinion that the mission of the college was to develop high-level lessons and to become the university college, a centre of higher education for all the Albanians. De Rada could state that: "The College opened a new sweet and huge bright door to all Arbëresh homes, It has always been a bright centre of freedom for all of us. "Working at that college De Rada collaborated with prominent Albanian personalities of renaissance as: Zef Jubani of Thimi Mitko. He had periodic cooperation with the Shkodra magazine "Hylli i Dritës".

In the course of that time, the Great Albanian teacher, patriot, and hero of the people, first director of the normal school of Manchester, Luigj Gurakuqi was the student of De Rada.

The releaser and the precious scholar Alexander Xhuvani served as the Albanian language teacher for three years in "St. Mitër Korona".

\section{The Contribution of De Rada in the Albanian Language}

Under the attention of De Rada journalism was much developed. In 1848 he published "Fiamuri Arberi", the first Albanian press notebook, which became a real flag of our national issue, tribune of patriotism and of national defence, where among other issues being raised, was laid down the demand for the Albanian autonomy. In the sixth edition of "Flag Arberi ' De Rada would express his political patriotic views, stating among other questions as: "We do not go to Montenegro / neither nor to Serbia/ neither nor to Austria/ to Turkey/ to Greece / we want only autonomy. / What a shame to Albania if it misses nationality".

The efforts of De Rada for delivery, extension and evaluation of the Albanian language as the oldest and richest language have been ongoing process. In 1899, De Rada published "Caratteri della lingua Albanese, Suoi Monumenti Nell'eta' Preistorica", followed by "Grammatica della lingua inglese", "Anthology inglese", "Lingue della Abecedario inglese" and a series of literary works in the printing house "Katanzara". Meanwhile the publications of De Rada became the object of the study work of the Albanologists. While working as the editor of the magazine "Shejzat", Martin Camaj closely jointed the world of the Arberesh issues, which became the object of his work study, thus becoming a professor of the Albanological studies. One of the most prominent figures of the Albanian education, science and culture, Eqrem Çabej won the title PhD in the Arbëresh studies area, accompanied with a series of studies in this field, followed by many important names of the Albanian culture as Shaban Demiraj, At Justin Rrota, Androkli Kostallari, Jup Kastrati, Jorgji Gjinari, Gjovalin Shkurtaj, Ethem Likaj, etc.

De Rada was the first fighter who worked to unify the spoken and written literary Albanian language. Under the influence of Italian Language, as well as under the influence of the Roman Catholic culture, the arbëresh writers have used mainly Latin alphabet. Writers, who used the Latin alphabet in their writings in some cases, have also used the Greek alphabet letters to meet phonetic demands. Sometimes unable to accomplish the requirements of the given Albanian phonetic letters in writing that were such that did not met by Latin alphabet, Greek letters were also used. Thus the Latin alphabet supplemented by Greek letters are written by the poets like: Nikollë Keta, Zef Skiroi, De Rada, Mikel Markianoi, Nikoll Filia etc, while Lekë Matrenga and Jul Varibova have used only the Latin alphabet.

By the initiative of De Rada, in 1895, in the small Calabrian town of Korilianos among others was settled to accept a common alphabet after his alphabet for all his Arbëresh community. Here, De Rada expressed the opinion that we have a simple and easy alphabet to learn.

\section{Conclusion}

All the most outstanding teachers embraced the same time the thesis: The use of Latin alphabet, which would be easy to learn. With hundreds of political and pedagogical articles written by the authors of the Renaissance time as Konstand Kristoforidhi, Sami Frashëri Pandeli Sotiri, Hoxha Tahsin, Mat Logoreci etc., he could be able to achieve the objective for the use of the Latin alphabet, for mastering easier the native language and to further develop the Albanian culture.

In 1836 De Rada for the first time published in Napoli "Songs of Milosaos". In the foreword of this wonderful lyric poem dedicated to his friend Raffaele Zagarese, a powerful researcher, the arberesh scholar expressed deep concern for the preservation of the Albanian identity and arberesh folk songs. "The perception of these songs," as he says, "the inspiration to write Milosao was found in the origin among this confusion". 
Generations of students have experienced the emotion and strong message of "the Songs of Milosaos" they could convey, Albanian hero who strongly loves his life, but at the same time dies as a soldier to protect the motherland. The Quote of Milosao "The day of Arber is coming" sounds a source of inspiration, pride and patriotism in this annual 100th independence event for Albanians everywhere around the world.

Even today his creative work is an inspiration source and a subject of study for a considerable number of albanologists, linguists and teachers of the Albanian language.

\section{References}

Altimari F., (1994) Outlines of the history of arbëreshe linguistics in "Italian-Albanian dialects ", edited by F. Altimari and L.M. Savoia, Bulzoni Editore, Rome,

Çabej E., (1972) Issue of origin Italy Arbëresh settlements mainly in the light of language and their personal names in "St. Fil. ', 2, p. 2334.

Çabej E., (1975) History language and structural dialect of Arbëresh in Italy, in "St. Fil. , 2, 1975, p. 51-69 and in the world of Arbëresh in Italy, Tirana.

Çabej E., (1969) Albanian settlements in Italy and their language, the 2nd Conference of Albanological Studies", Vol. III.

Shkurtaj GJ., (1986) Some notes on Arbëreshs dialect of Marçeduza, in "Studies in honor of A. Xhuvani", Tirana, p. 513-17 
